\title{
Benign occipital unicameral bone cyst causing lower cranial nerve palsies complicated by iophendylate arachnoiditis
}

\author{
W. G. BRADLEY, R. M. KALBAG, P. S. RAMANI, \\ AND B. E. TOMLINSON \\ From the Departments of Neurology, Neurosurgery, and Neuropathology, \\ Newcastle University Hospitals Group, and the University of Newcastle upon Tyne
}

SYNOPSIS A 20 year old girl presented with a history of neck and occipital pain for six weeks, which was found to be due to a unicameral bone cyst of the left occipital condylar region. The differential diagnosis of bone cysts in the skull is discussed. Six months after the operation, the patient again presented with backache due to adhesive arachnoiditis. The latter was believed to have arisen as a result of a combination of spinal infective meningitis and intrathecal ethyl iodophenyl undecylate (iophendylate, Myodil, Pantopaque). The nature of meningeal reactions to iophendylate and the part played by intrathecal corticosteroids in relieving the arachnoiditis in the present case are discussed.

Localized radiologically cystic bone lesions are occasionally found in the long bones of the limbs but more rarely occur in the vertebral column and flat bones, including the skull. There are many causes, including enchondroma, chondroblastoma, chondromyxoid fibroma, simple fib. roma, lipoma, osteoblastoma, giant cell tumour (osteoclastoma), haemangioma, simple unicameral bone cyst, aneurysmal bone cyst, neurofibroma in Von Recklinghausen's disease, epidermoid cyst, eosinophilic granuloma (histiocytosis $\mathrm{X}$ ), osteitis fibrosa cystica of hyperparathyroidism, fibrous dysplasia, ganglion cysts, osteogenic sarcoma, chondrosarcoma, Ewing's sarcoma, myeloma, leukaemia, secondary malignant deposit, as well as cysts related to trauma and to degenerative arthritis, inflammatory disease including osteomyelitis, and a bone infarct.

Bone cysts in the skull are rare, and as such are usually not considered in the differential diagnosis of conditions causing intracranial damage. Their benign nature in most instances makes it important to know of this rare occurrence, in order to plan the appropriate investigation and treatment. The unique patient reported here presented with neck pain and lower cranial nerve palsies, which proved to be due to a simple unicameral bone cyst of the occipital bone. The nature of this and other bone cysts which may affect the skull is reviewed. The postoperative course was complicated by an episode of spinal arachnoiditis, which was probably due to the combination of an attack of infective spinal meningitis in the presence of intrathecal ethyl iodophenyl undecylate (iophendylate, Myodil, Pantopaque). The nature of iophendylate arachnoiditis and its treatment are briefly discussed.

\section{CASE HISTORY}

M.L. (N.44515) Six weeks before admission this 20 year old girl gradually developed occipital headaches and pains at the back of the neck. These were aching in character, constant night and day, and gradually worsened. The pain radiated over the vertex to the frontal region, and down the neck to the shoulders, particularly on the left side. Movement of the head and neck made the pain worse. She felt well, but was increasingly distressed by the pain which began to keep her awake at night. There was neither fever nor deafness. Her family doctor saw her on several occasions in the six weeks before admission, and the 


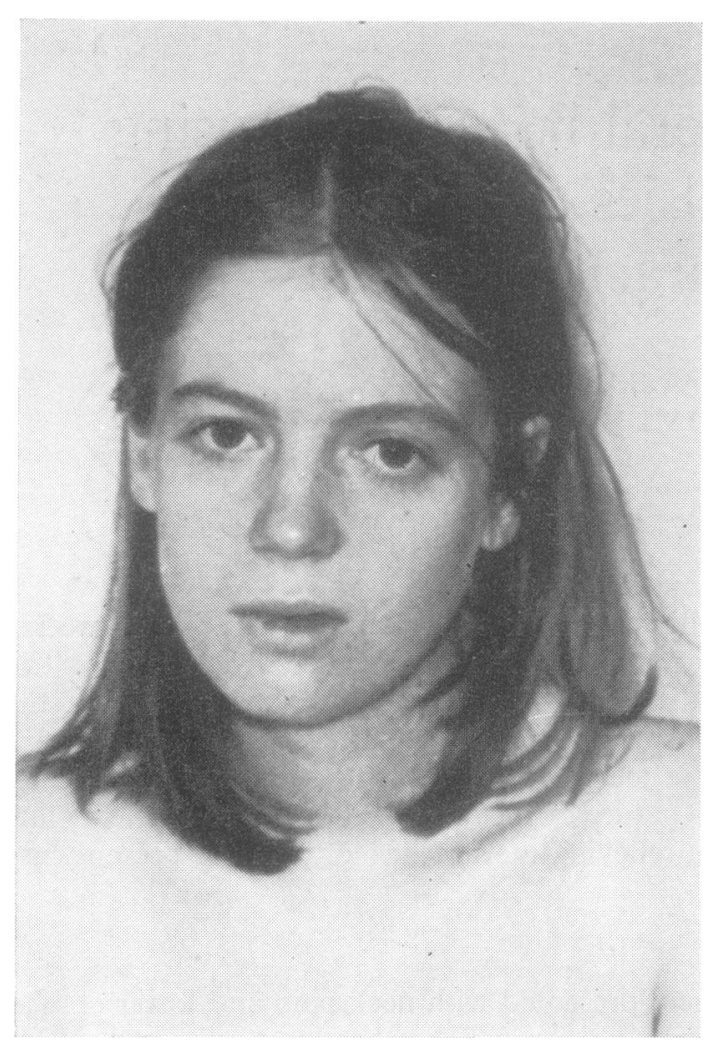

FIG. 1. The position of the patient's head and neck at presentation.

only abnormality found was a slightly pink left ear drum. She had two five-day courses of antibiotics without effect upon the pain.

On examination, it was seen that her head and neck were deviated to the right (Fig. 1), and all attempts at active or passive neck movement were resisted because of pain. The left tympanic membrane appeared slightly dull and pink and there was a very slight degree of conductive deafness on the left. On the first examination the tongue deviated slightly to the left. Over the next few days the occipital pain and neck stiffness improved considerably, and the deviation of the tongue disappeared. About a week later the pain in the neck recurred, together with evidence of mild paresis of the left $7 \mathrm{th}$, 9th, 10th, and 12th cranial nerves.

INVESTIGATIONS Haemoglobin was $13.6 \mathrm{~g} / 100 \mathrm{ml}$; white blood cell count (WBC) $5,500 / \mathrm{mm}^{3}$; and erythrocyte sedimentation rate (ESR) $7 \mathrm{~mm}$ in one hour. Blood urea and electrolytes were normal. Cerebrospinal fluid (CSF) protein was $40 \mathrm{mg} / 100 \mathrm{ml}$ without pleocytosis. Blood serology for syphilis was negative. Chest and cervical spine radiographs were of normal. Initially radiographs of the skull were difficult to obtain because of neck pain and restriction of 0 movement, and no abnormality was detected. Because a lesion at the atlanto-occipital region was ? initially suspected, a prone and supine myelogram was performed, revealing no abnormality. As the neck pain subsided, radiographs of the base of the $\vec{\Rightarrow}$ skull were obtained showing an area of bone destruction involving the region of the jugular foramen, the hypoglossal canal, and extending to the region of the sigmoid venous sinus laterally, and to the anterolateral margin of the foramen magnum medially (Figs 2 and 3). The margin of the osteolytic area was is well defined, indicating that the lesion was of some $\overrightarrow{0}$ duration. The sella turcica, dorsum sellae, and vault of the skull were normal. Tomograms of the jugular $\bar{\omega}$ foramen (Fig. 4) showed that the erosion of bone also extended into the left occipital condyle, only a thin shell of which remained. Selective left external carotid and left vertebral arteriograms were normal.

ENT CONSULTATION (Mr Ivor Frew) The appeapo 응 ances of the left ear drum were similar to those of secretory otitis media, and under general anaesthesia myringotomy produced more than $5 \mathrm{ml}$ of straw $\vec{w}$ coloured fluid which welled out of the middle eas $\mathbb{D}$ The fluid was sterile, contained no cells and had $g$ protein concentration of $5 \cdot 3 \mathrm{~g} / 100 \mathrm{ml}$.

The radiographic evidence suggested that the lesion was of long standing, but the short history and the extensive erosion of bone suggested the possi- 9 bility that the lesion was a primary or secondary carcinoma or an unusual infiltration such as an eosinophilic granuloma of bone. A skeletal survey failed to reveal any other bony erosion. A search was made for evidence of generalized disease, and it was found that in the two weeks after her admission $\mathbb{Q}$ her haemoglobin had fallen to $10.9 \mathrm{~g} / 100 \mathrm{ml}$, and $\overrightarrow{\vec{P}}$ that there were $2 \%$ reticulocytes in the peripheral blood film. The white blood cell count had fallen to $2,700 / \mathrm{mm}^{3}$ with a normal differential count. No abnormal cells were seen in the blood film. The ESR had risen to $31 \mathrm{~mm}$ in one hour. Liver function tests were normal except that the serum aspartate aminotransferase (SGOT) was 57 units/ml (normal less than 35), and the alanine aminotransferase (SGPT) 65 units/ml (normal less than 45). Sternal marrow aspirate and bone marrow needle biopsy showed no abnormality. Over the next week the haemoglobin WBC, SGOT, and SGPT returned to $\frac{7}{0}$ normal. The explanation for the abnormalities was not clear, but they may have resulted from the two of general anaesthetics, and two radiographic contrast $N$ studies which she had undergone. 


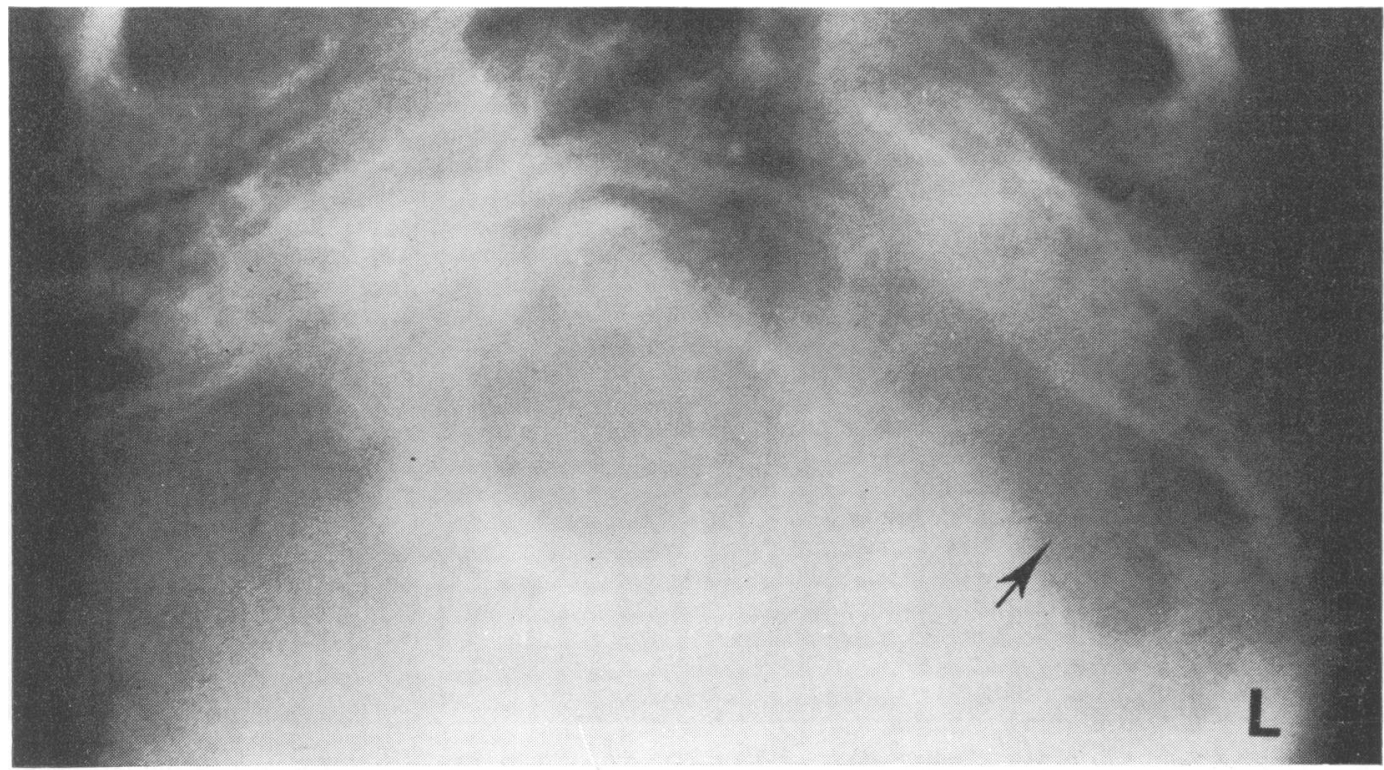

FIG. 2. Basal view of the skull showing erosion in the occipital bone (arrow).

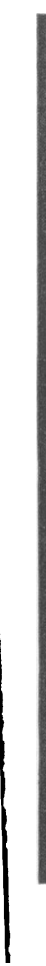

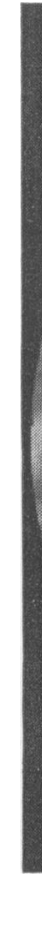

FIG. 3. A special view of the mastoid and occipital region to show erosion of the left occipital bone (arrow).

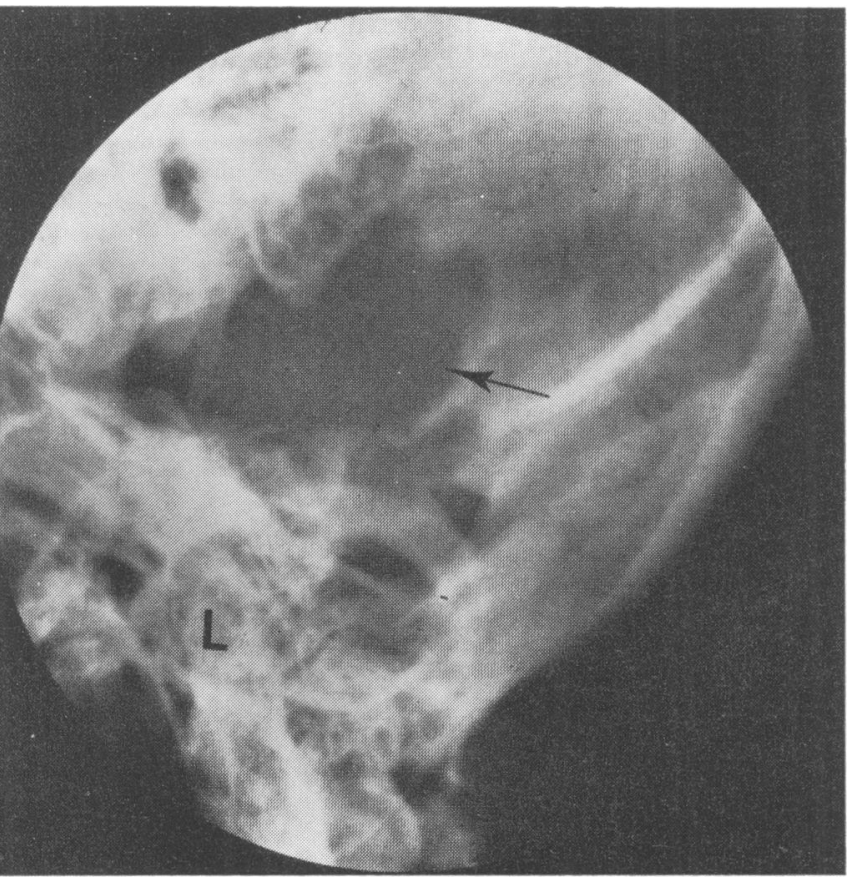


FIG. 4. Tomographic cut in the coronal plane of the level of the odontoid process. The loss of the left occikita condyle, and erosion of the adjacent occipital bone are clearly shown (arrow).

OPERATION A left suboccipital exploration revealed markedly thin bone behind the left mastoid process with a cyst lying between the inner and outer tables of the squamous occipital bone. The cyst lay in the region of the left mastoid process and occipital condyle, and had eroded through into the middle ear cavity and to the dura mater of the posterior fossa in the region of the hypoglossal canal. The cavity of the cyst did not communicate with any of these adjacent structures. The cyst fluid was yellow, and similaf to that obtained from the middle ear at myringotom The interior was lined by smooth membrane, was divided into two intercommunicating shaBow loculi by a small bony partition approximately inthe situation of the occipital condyle. The lining of the cyst did not bleed excessively when cut. The interiog

FIG. 5. Section through the fibrous wall $(\mathrm{F})$ of the cyst $(\mathrm{C})$ and surrounding bone $(\mathrm{B})$ of the occipital region. Haemosiderin-laden macrophages and some fresh haemorrhage are present at $\mathrm{H}$. The fibrous cyst wall is sparsely vascular. Decalcified tissue. $H$ and $E$, $\times 125$.

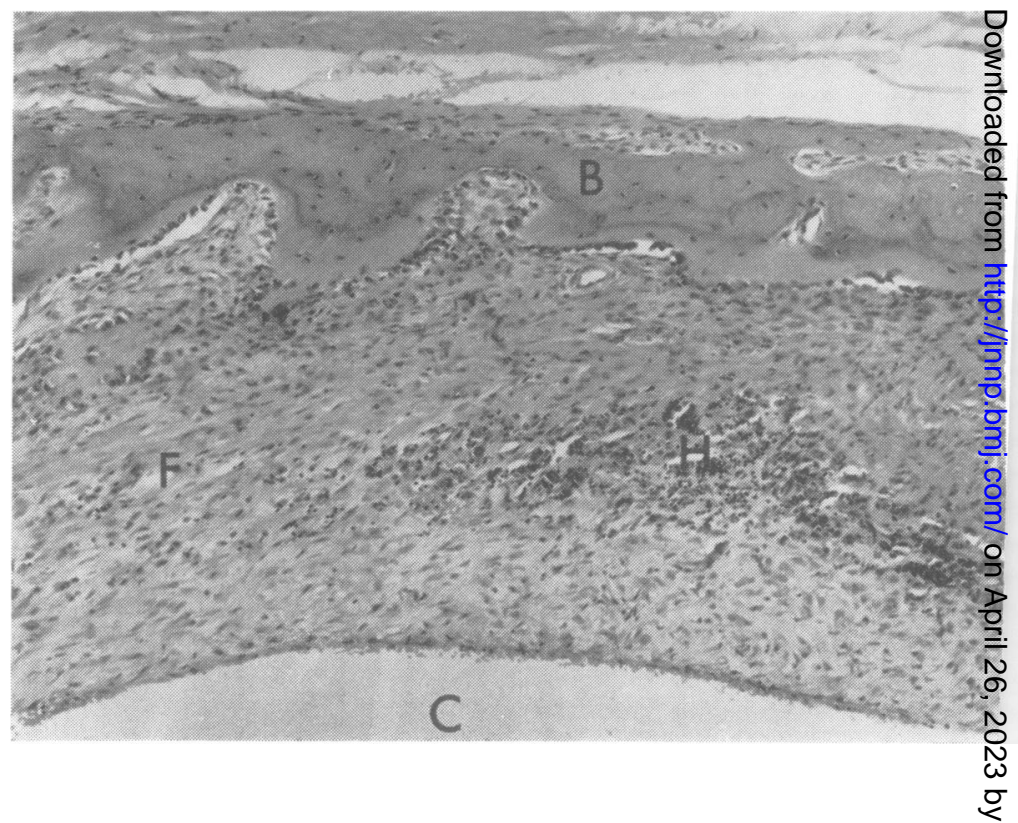


of the cyst was curetted and treated with absolute alcohol.

HISTOLOGY The cyst wall consisted of well-differentiated fibrous tissue in which there was a thin layer of bone, and some foci of calcification (Fig. 5). Osteoclastic activity was prominent on the cyst-side of the bone (Fig. 6), and in places the cyst had eroded through the bone (Fig. 7). There were deposits of haemosiderin in the fibrous wall of the cyst, which was not particularly vascular. The appearances were those of a simple unicameral bone cyst.
POSTOPERATIVE COURSE After the operation she was placed in a modified Minerva collar for eight weeks. The occipital headaches were relieved by the operation. Three months after the operation her head and neck movements were entirely normal, and tomograms of the base of the skull showed early formation of new bone in the eroded area. There was mild residual weakness and wasting of the left side of the tongue.

Six months later she was readmitted with low lumbar backache radiating down into the legs progressively increasing for 10 days. Coughing, sneezing,
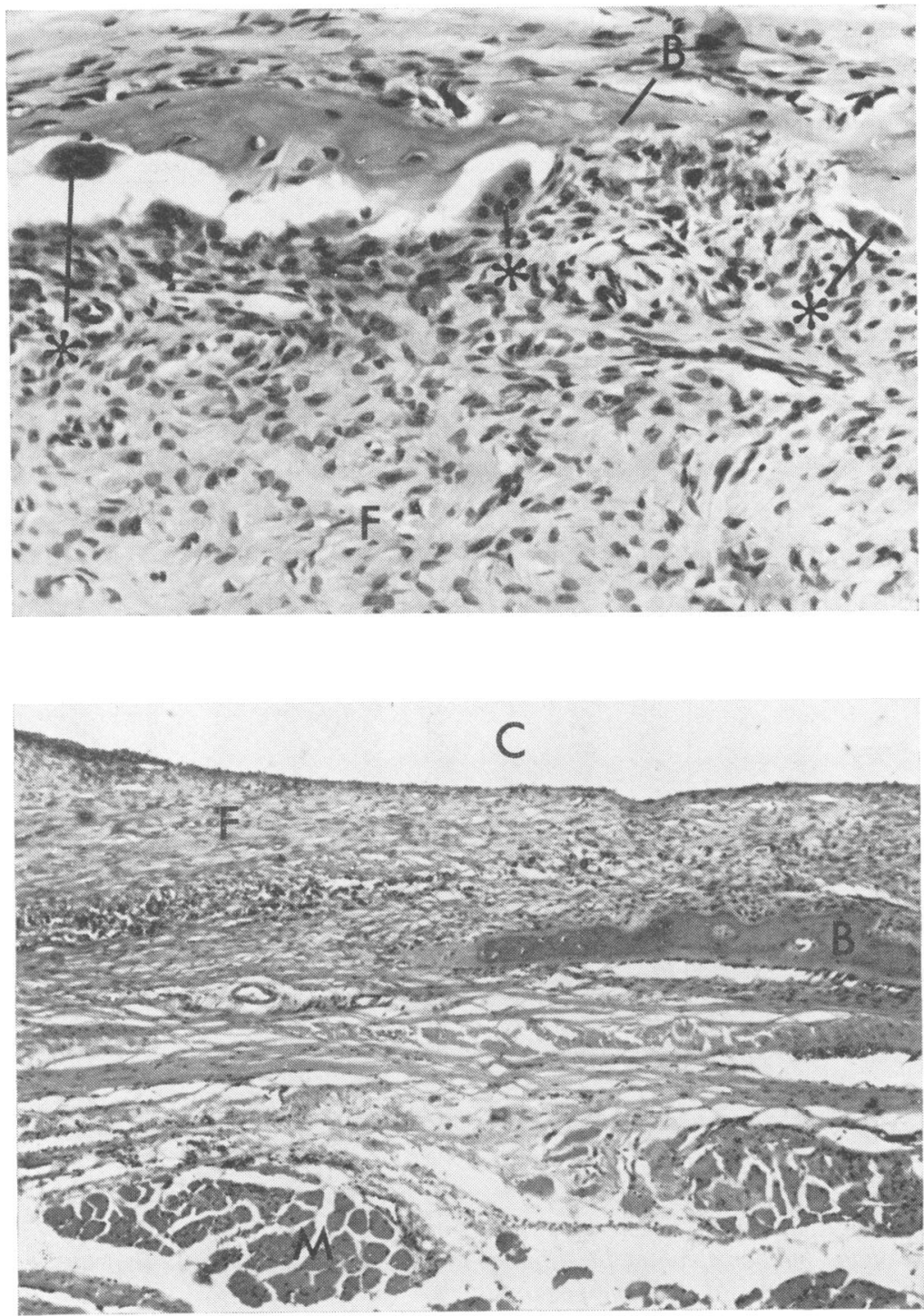

FIG. 6. High power view of the junction of the fibrous cyst wall $(\mathrm{F})$ with the occipital bone (B) showing prominent osteoclast activity (*). Decalcified tissue. $H$ and $E$, $\times 320$.
FIG. 7. Section through the fibrous wall $(\mathrm{F})$ of the cyst $(\mathrm{C})$ at the level of erosion through the occipital bone (B) to lie immediately subjacent to the occipitalis muscle (M). Decalcified tissue. $H$ and $E, \times 80$. 
and bending had no effect upon the pain, but lying supine and sitting exacerbated it. Neurological examination revealed few abnormalities. The tendon reflexes in the lower limbs were normal, and the plantar responses flexor. Abdominal reflexes had, however, disappeared. Straight leg raising was full, but painful throughout the range of movement. Sensation was normal. She was very distressed by the pain. Radiographs of the spine showed iophendylate remaining from the previous myelogram fixed in the lumbar region among the nerve roots of the cauda equina producing a linearly-streaked picture (Fig. 8). The appearances were interpreted as being those of adhesive arachnoiditis. Repeated attempts at lumbar puncture failed to obtain CSF, and on three occasions $10 \mathrm{mg}$ hydrocortisone were injected into the area of the lumbar theca, each with considerable improvement in the pain.

While testing spinal movements after the second injection of hydrocortisone, clear fluid was noted to drip from her nose. Only then did she comment thas she had had this since the time of the operation, and it became clear that she had cerebrospinal fluie rhinorrhoea. She also revealed that three week before the onset of the lumbar backache whicho precipitated her admission, she had had a sever headache, followed by rigors and lumbago for three. days. This had settled spontaneously. It was pres sumed that she had had an episode of bacterial meningitis at that time.

SECOND OPERATION The occipital region wa? explored and a hole in the dura mater near the position of the occipital condyle was found. This allowed access of CSF from the cisterna magna int $\circledast$ the middle ear. The hole was covered with periळ cranium and muscle, while the opening into the mastoid air cells was sealed with bone wax.

POSTOPERATIVE COURSE The second operation abol $\vec{\omega}$ ished the cerebrospinal fluid rhinorrhoea. When she

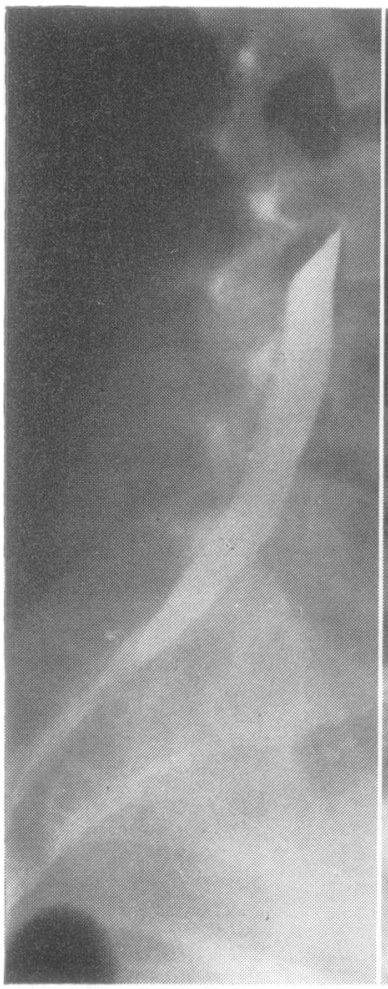

(a)

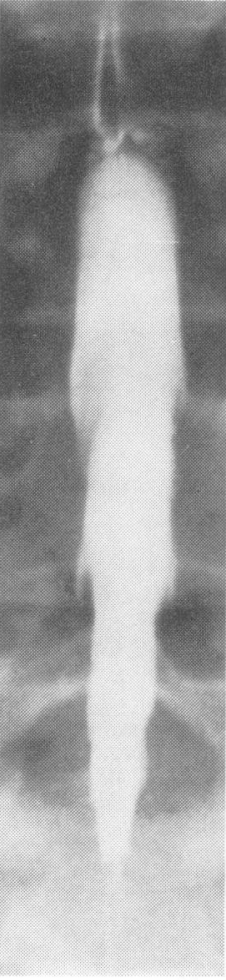

(b)

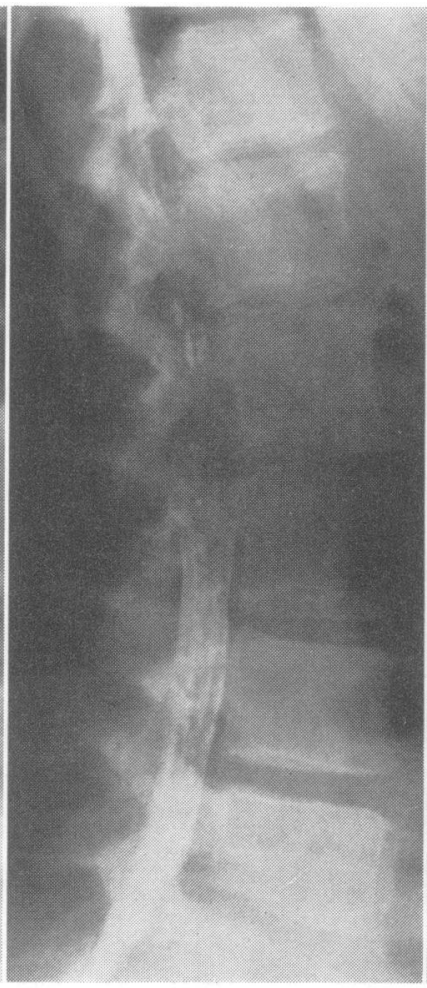

(c)

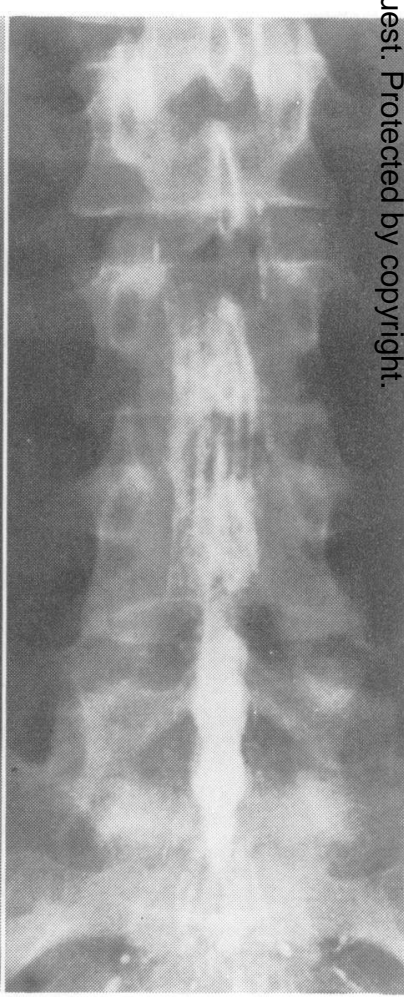

(d) 
had recovered from the operation, a further lumbar puncture was performed to inject $80 \mathrm{mg}$ methylprednisolone. A free flow of cerebrospinal fluid was obtained on this occasion. She was discharged from hospital free of backache. A further episode of severe lumbar backache occurred a month after the operation. This time the reflexes in the lower limbs were exaggerated and the plantar responses equivocal. The backache, however, settled spontaneously over the next two weeks, and the pyramidal tract disturbance disappeared.

Four months later she was entirely symptom free, and leading a normal life. The only abnormality on neurological examination was a mild left hypoglossal nerve paresis. Radiographs of the lumbar spine at this time showed a considerable reduction in the amount of iophendylate around the cauda equina (Fig. 9).

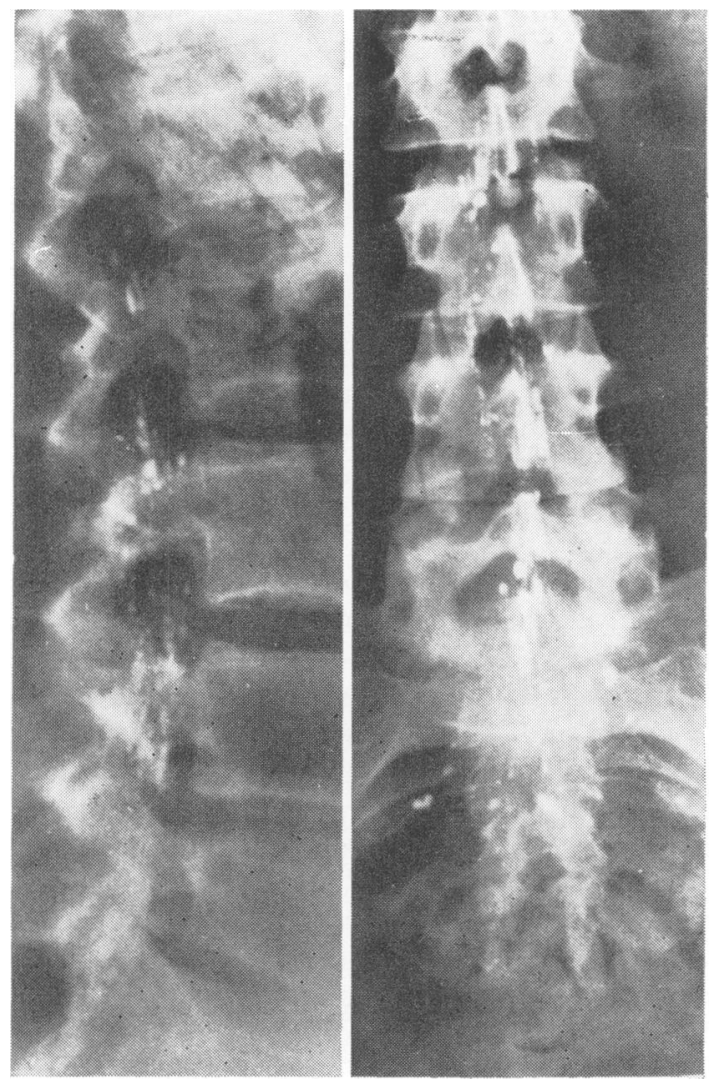

FIG. 9. (a) Lateral and (b) anteroposterior radiographs of the lumbar spine six months after the presentation with arachnoiditis, showing a greatly reduced amount of iophendylate present.
Eighteen months after the mitral operation, radiographs of the occipital region showed regeneration of bone in the region of the occipital condyle.

\section{DISCUSSION}

This patient presented with only six weeks of occipital headache, leading to restriction of movement of the neck and mild paresis of the left 7 th, 9th, 10th, and 12th cranial nerves together with mild conductive deafness on the left. The radiological and pathological features of the cyst, however, leave little doubt that the condition had been present for many months, probably years. It is probable that the cyst presented only when it eroded the occipital bone in the region of the condyle to impinge upon the dura mater, and the jugular and hypoglossal canals causing the 9th, 10th, and 12th cranial nerve pareses. It must also have invaded the middle ear cavity at the same time producing conductive deafness and facial nerve paresis. The fluid obtained at myringotomy was the same proteinacious yellow fluid that was seen within the cyst at the time of the occipital exploration.

In addition to the conditions listed in the introduction as causing solitary cystic erosion of bone, a number of other erosive conditions may more specifically arise from the middle ear cleft and mastoid area. These include a primary cholesteatoma (epidermoid tumour), a cholesteatoma secondary to chronic suppurative otitis media, a carcinoma of the middle ear cleft, chronic infections including those due to tuberculosis and fungi, and osteomyelitis.

Nomura et al. (1971) reported a woman with a cyst arising in the mastoid-middle ear region, which contained dark brown, cholesterol-rich fluid, and an isolated area of cuboidal epithelium. They were not certain of its exact origin, but it clearly differed from the present case. Go (1970) reported a patient with a parietal leptomeningeal cyst, and Dunkser and McCreary (1971) described a patient with a similar cyst in the occipital region of the skull. Both arose from a head injury some years previously, which resulted in a dural tear. This allowed CSF to erode between the inner and outer tables of the skull producing an expanding cystic lesion. These differ from the present case in which there was no communication between the cyst and the CSF pathways. 
Aneurysmal bone cysts may occasionally occur in the skull, presenting as an expanding and space-occupying lesion. The proportion of such cysts occurring in the skull bones is about 2-4\% (Lichtenstein, 1957; Tillman et al., 1958; Dabska and Buraczewski, 1969). Odeku and Mainwaring (1965) described a large occipital aneurysmal bone cyst in a Negro boy of $6 \frac{1}{2}$ years producing chronic raised intracranial pressure. Constantini et al. (1966) described an aneurysmal bone cyst arising from the orbital bone of a girl of 14 years presenting as a frontal space-occupying lesion. Bhende and Kothare (1950) and Jeremiah (1965) each described a case of an aneurysmal bone cyst arising in the temporal bone. Burns-Cox and Higgins (1969) described a girl of 13 years with an enlarging frontal swelling due to an aneurysmal bone cyst, without intracranial complications.

There can, however, be no confusion between the cyst in the present case and an aneurysmal bone cyst. The latter consists of spongy tissue comprising numerous dilated blood vessels and fibrous tissue (Lichtenstein, 1950, 1957; Tillman et al., 1968; Dabska and Buraczewski, 1969). As this cyst is opened, blood wells into the operative field, an appearance not seen in the present case.

The cyst in the present case contained clear, golden yellow proteinacious fluid, surrounded by a fibrous wall which was not markedly vascular, an appearance corresponding most closely to the descriptions of unicameral bone cysts (Jaffe and Lichtenstein, 1942; Garceau and Gregory, 1954; Aegerter and Kirkpatrick, 1968). Simple unicameral bone cysts are most common in the second decade of life, and males are twice as frequently affected as females. Long bones are the main ones affected, $75 \%$ of all cases being in the humerus or femur. It has been suggested that they may arise as a result of venous obstruction or various cartilagenous or fibrous rests occurring during bone development (Cohen, 1960, 1970; Broder, 1968). The most effective treatment is curettage, and packing the cavity with bone chips (Neer et al., 1966), though the latter procedure was not performed in the present case because of the intimate relationships of important structures. There are two unique features about the present cyst. Firstly, we have found no previous reference to a unicameral cyst arising in skull bones, and, secondly, it is extremely unusual for a unicameral cyst in its more common sites to erode through the bone in the absence of a fracture.

The postoperative course in this patient was 0 complicated. Cerebrospinal fluid rhinorrhoea clearly precipitated an attack of spinal infective $\stackrel{\overbrace{}}{\stackrel{ }{\bar{m}}}$ meningitis six months after the initial operation. Two weeks later severe lumbago and sciatica developed. By this time marked adhesive arachnoiditis was present, as indicated by the dry들 lumbar punctures and the radiological appearance of iophendylate firmly fixed among the roots $\frac{5}{7}$ of the cauda equina. Intrathecal corticosteroids $\stackrel{\Phi}{\triangle}$ appeared to improve the arachnoiditis. Four o months later not only was the patient asympto- $\vec{\circ}$ matic, but the iophendylate had in part at least been removed from the cauda equina region.

Ethyl iodophenylundecylate (iophendylate, Myodil, Pantopaque) was introduced clinicallyo in 1944 (Ramsey et al., 1944; Steinhausen et a 1944), and has been found to be a satisfactof contrast medium for myelography. It has relag $\vec{\circ}$ tively ideal physical and radiographic propertieo and complications directly attributable to its uße are extremely infrequent (Peacher and Rober $\mathbb{Q}=\overrightarrow{0}$ son, 1945). There are, however, rare reports transient mild meningeal reactions including $\mathbb{\mathbb { D }}$ meningism, neck rigidity, headache, backachę, increased cell count and protein concentration the cerebrospinal fluid, fever, malaise, and ileus $\vec{\omega}$ (Steinhausen et al., 1944; Peacher and Robert- + son, 1945; Schnitker and Booth, 1945; Ford and Key, 1950; Luce et al., 1951; Davies, 1956). These reactions usually occur five to 24 hours after myelography and subside within 72 hours (Schnitker and Booth, 1945). A small proportion $\stackrel{\mathbb{\perp}}{\circ}$ of the population show marked hypersensitivity $\vec{O}$ to iodine and iophendylate. The introduction of 3 any quantity of iophendylate into the sub-? arachnoid space of these patients may produce a: dramatic picture of meningeal irritation.

A number of severe reactions to iophendylate. myelography not necessarily due to hypersensitivity have been reported, including arachnoiditis, meningitis, and ventriculitis (Tarlov, 1945; Erickson, 1953; Davies, 1956; Taren, 1960; Mason and Raaf, 1962; Imielinski and Chmielewski, 1971). These meningitic reactionso seem to occur with individual batches of iophendylate, and in such cases there is always the question whether the iophendylate was con- 
taminated with toxins such as disinfectants or preservatives. After such an outbreak due to a suspect batch of iophendylate, a follow-up of nearly 100 patients undergoing myelography with new batches of iophendylate failed to reveal a single case of severe meningitic reaction in those patients with normal myelograms (StewartWynne et al., 1973).

Iophendylate may also react adversely with some abnormal constituent of the CSF. Howland et al., (1963), Howland and Curry, (1966a, b), Howland et al., (1966) showed that iophendylate mixed with blood caused severe meningeal reactions in dogs, and methylprednisolone added to the blood and iophendylate gave considerable protection against the meningitis. Bergeron et al. (1971) confirmed these findings in monkeys, and advocated that iophendylate should be removed at the conclusion of myelography, and should not be injected if the cerebrospinal fluid was bloody for any reason. In the United Kingdom it is not the routine practice to remove iophendylate at the end of myelography, yet the complication rate has not proved to be higher than in other countries where removal is attempted.

In the patient reported here, it is presumed that the combination of spinal meningitis secondary to the cerebrospinal fluid rhinorrhoea led, in the presence of iophendylate remaining after myelography, to a marked adhesive arachnoiditis. Circumstantial evidence suggests that intrathecal corticosteroids may have been effective in alleviating this arachnoiditis.

We are grateful to Dr Mohamed Banna for the initial radiological investigations, and to Mrs Evelyn Mooney for secretarial services.

\section{REFERENCES}

Aegerter, E., and Kirkpatrick, J. A., Jr (1968). Orthopedic Diseases, pp. 491-500. 3rd edn. Saunders: Philadelphia.

Bergeron, R. T., Rumbaugh, C. L., Fang, H., and Cravioto, H. (1971). Experimental Pantopaque arachnoiditis in the monkey. Radiology, 99, 95-101.

Bhende, Y. M., and Kothare, S. N. (1950). Aneurysmal bone cyst: case report. Indian Medical Gazette, 85, 544-546.

Broder, H. M. (1968). Possible precursor of unicameral bone cysts. Journal of Bone and Joint Surgery, 50A, 503-507.

Burns-Cox, C. J., and Higgins, A. T. (1969). Aneurysmal bone cyst of the frontal bone. Journal of Bone and Joint Surgery, 51B, 344-345.

Cohen, J. (1960). Simple bone cysts. Studies of cyst fluid in six cases with a theory of pathogenesis. Journal of Bone and Joint Surgery, 42A, 609-616.
Cohen, J. (1970). Etiology of simple bone cyst. Journal of Bone and Joint Surgery, 52A, 1493-1497.

Constantini, F. E., Iraci, G., Benedetti, A., and Melanotte, P. L. (1966). Aneurysmal bone cyst as an intracranial space-occupying lesion. Case report. Journal of Neurosurgery, 25, 205-207.

Dabska, M., and Buraczewski, J. (1969). Aneurysmal bone cyst. Pathology, clinical course and radiologic appearances. Cancer, 23, 371-389.

Davies, F. L. (1956). Effect of unabsorbed radiographic contrast media on the central nervous system. Lancet, 2, 747748.

Dunkser, S. B., and McCreary, H. S. (1971). Leptomeningeal cyst of the posterior fossa. Case report. Journal of Neurosurgery, 34, 687-692.

Erickson, T. C., and van Baaren, H. J. (1953). Late meningeal reaction to ethyl iodophenylundecylate used in myelography. Report of a case that terminated fatally. Journal of the American Medical Association, 153, 636-639.

Ford, L. T., and Key, J. A. (1950). An evaluation of myelography in the diagnosis of intervertebral-disc lesions in the low back. Journal of Bone and Joint Surgery, 32A, 257-266.

Garceau, G. J., and Gregory, C. F. (1954). Solitary unicameral bone cyst. Journal of Bone and Joint Surgery, 36A, 267-280.

Go, K. G. (1970). A case of a bone cyst of the skull, overlying a small dural tear. Archivum Chirurgicum Neerlandicum, 22, 183-187.

Howland, W. J., and Curry, J. L. (1966a). Experimental studies of Pantopaque arachnoiditis. I. Animal studies. Radiology, 87, 253-257, 260.

Howland, W. J., and Curry, J. L. (1966b). Pantopaque arachnoiditis. Experimental study of blood as a potentiating agent and corticosteroids as an ameliorating agent. Acta Radiologica, Diagnosis, 5, 1032-1041.

Howland, W. J., Curry, J. L., and Butler, A. K. (1963). Pantopaque arachnoiditis. Experimental study of blood as a potentiating agent. Radiology, 80, 489-491.

Howland, W. J., Curry, J. L., and Richey, D. (1966). Experimental studies of pantopaque arachnoiditis. Part 3. Clinical studies in progress. Radiology, 87, 258-260.

Imielinski, B. L., and Chmielewski, J. M. (1971). Arachnoïdite adhésive intrarachidienne à la suite de myélographies à éthiodane (Pantopaque). Journal de Radiologie, d'Electrologie et de Médecine Nucléaire, 52, 31-34.

Jaffe, H., and Lichtenstein, L. (1942). Solitary unicameral bone cyst. With emphasis on the roentgen picture, the pathologic appearance and the pathogenesis. Archives of Surgery, 44, 1004-1025.

Jeremiah, B. S. (1965). Aneurysmal bone cyst of the temporal bone. Journal of the International College of Surgery, 43, 179-183.

Lichtenstein, L. (1950). Aneurysmal bone cyst. Cancer, 3, 279-289.

Lichtenstein, L. (1957). Aneurysmal bone cyst. Observations on fifty cases. Journal of Bone and Joint Surgery, 39A, 873882.

Luce, J. C., Leith, W., and Burrage, W. S. (1951). Pantopaque meningitis due to hypersensitivity. Radiology, 57, 878-881.

Mason, M. S., and Raaf, J. (1962). Complications of Pantopaque myelography. Case report and review. Journal of Neurosurgery, 19, 302-311.

Neer, C. S., Francis, K. C., Marcove, R. C., Terz, J., and Carbonara, P. N. (1966). Treatment of unicameral bone cyst. A follow-up of one hundred seventy-five cases. Journal of Bone and Joint Surgery, 48A, 731-745.

Nomura, Y., Takemoto, K., and Komatsuzaki, A. (1971). The mastoid cyst. Report of a case. Laryngoscope, 81, 438446.

Odeku, E. L., and Mainwaring, A. R. (1965). Unusual 
aneurysmal bone cyst. A case report. Journal of Neurosurgery, 22, 172-176.

Peacher, W. G., and Robertson, R. C. L. (1945). Pantopaque myelography: results, comparison of contrast media, and spinal fluid reaction. Journal of Neurosurgery, 2, 220-231.

Ramsey, G. H., French, J. D., and Strain, W. H. (1944). lodinated organic compounds as contrast media for radiographic diagnoses. 4. Pantopaque myelography. Radiology, 43, 236-240.

Schnitker, M. T., and Booth, G. T. (1945). Pantopaque myelography for protruded disks of the lumbar spine. Radiology, 45, 370-376.

Steinhausen, T. B., Dungan, C. E., Furst, J. B., Plati, J. T. Smith, S. W., Darling, A. P., Wolcott, E. C., Jr, Warren, S. L., and Strain, W. H. (1944). Iodinated organic com- pounds as contrast media for radiographic diagnoses. III. Experimental and clinical myelography with ethylo iodophenylundecylate (Pantopaque). Radiology, 43, 230-

Stewart-Wynne, E., Davis, C., and Bradley, W. G. (1973) Unpublished observations.

Taren, J. A. (1960). Unusual complication following Pantopaque myelography. Journal of Neurosurgery, 17, 323-326.

Tarlov, I. M. (1945). Pantopaque meningitis disclosed at operation. Journal of the American Medical Association, 129, 1014-1016.

Tillman, B. P., Dahlin, D. C., Lipscomb, P. R., and Stewart, J. R. (1968). Aneurysmal bone cyst: an analysis of ninetyfive cases. Mayo Clinic Proceedings, 43, 478-495. 